\title{
Pembelajaran Ekonomi Pada Masa Pandemi Covid-19
}

\author{
Maskhur Dwi Saputra ${ }^{1}$ \\ ${ }^{1}$ Universitas Indraprasta PGRI, maskhurds.peunindra@gmail.com
}

\section{DOI}

https://doi.org/10.26740/jupe.v9n3.p61$\underline{69}$

\author{
Article history \\ Received \\ 15 November 2021 \\ Revised \\ 10 December 2021 \\ Accepted \\ 12 December 2021
}

\section{How to cite}

Saputra, M.D. (2022). Pembelajaran

Ekonomi Pada Masa Pandemi Covid-

19. Jurnal Pendidikan Ekonomi

(JUPE), 10(1), 61-69.

https://doi.org/10.26740/jupe.v9n3.p61$\underline{69}$

Kata Kunci: pembelajaran daring, pembelajaran ekonomi, guru ekonomi.

Keywords: online learning, economics learning, economics teacher.

\section{Corresponding author}

Maskhur Dwi Saputra

maskhurds.peunindra@gmail.com

\begin{abstract}
Abstrak
Penelitian ini bertujuan untuk mengetahui bagaimana guru ekonomi melakukan pembelajaran daring selama pandemi covid-19. Metode penelitian ini menggunakan jenis deskriptif kualitatif, sedangkan pengambilan data menggunakan wawancara dengan beberapa guru ekonomi di wilayah SMA Surakarta menggunakan telepon WhatsApp. Teknik pengambilan data menggunakan purposive dan snowball sampling. Hasil penelitian menunjukkan bahwa guru ekonomi di awal semester menyiapkan perangkat pembelajaran. Namun perangkat pembelajaran tersebut hanya mengedit dari semester sebelumnya, sehingga guru ekonomi tinggal menyesuaikan saja. Perangkat pembelajaran yang dibuat itu hanya sebagai syarat administrasi untuk laporan ke dinas pendidikan setempat. Perangkat pembelajaran tidak diimplementasikan ketika proses pembelajaran berlangsung. Guru ekonomi menggunakan beberapa media untuk tersambung ke peserta didik seperti WhatsApp Group, Google Classroom, Google Meet dan youtube. Selanjutnya untuk penilaian pembelajaran, guru ekonomi menggunakan aplikasi google form, quizzezz, quipper school, mentimeter, kahoot, serta software e-learning milik sekolah.
\end{abstract}

Abstract
This study seeks to find out how economics teachers carry out online learning during the COVID-19 pandemic. This research method uses a qualitative descriptive type, while data collected using interviews with several economics teachers in the Surakarta senior high schools using WhatsApp. The data were collected using purposive and snowball sampling. The results showed that the economics teachers prepared learning instruments at the beginning of the semester. However, the instruments were only the edited instruments from the previous semester. The economics teachers only adjusted them. The instruments made were only as administrative requirements for reports to the local education office. The instruments were not implemented during the learning process. Economics teachers used several media to connect with their students such as WhatsApp Group, Google Classroom, Google Meet, and YouTube. For learning assessment, they used Google Form, Quizzzz, Quipper School, Mentimeter, Kahoot, and the school's elearning software. 


\section{PENDAHULUAN}

Pendidikan merupakan bidang kehidupan yang sangat penting karena dapat menciptakan sumberdaya manusia yang unggul bagi suatu negara. Bidang pendidikan juga menjadi prioritas utama di Indonesia sebagai salah satu negara yang memiliki banyak penduduk, sehingga pendidikan di Indonesia harus diarahkan untuk mengembangkan kualitas penduduk tersebut. Tujuan pendidikan di Indonesia sendiri yaitu untuk mengambangkan potensi peserta didik agar mampu bersaing di kehidupan masyarakat (Depdiknas, 2003).

Potensi peserta didik harus diarahkan sesuai dengan perkembangan zaman. Pada saat sekarang ini perkembangan zaman terutama ilmu pengetahuan berkembang sangat cepat dan sulit diprediksi (Redhana, 2019), sehingga akan ada kemungkinan keterampilan saat ini tidak akan dipakai di masa yang akan datang (Karim, 2020). Oleh karena itu potensi peserta didik harus diarahkan untuk menghadapi perkembangan zaman yang sulit diprediksi tersebut.

Proses pengembangan potensi peserta didik tentunya tidak terlepas dari peran sekolah. Hal ini dikarenakan setiap hari peserta didik melakukan kegiatan di sekolah. Proses pengajaran di sekolah dilakukan oleh tenaga pendidik atau guru, karena unsur guru ini yang langsung berhadapan dengan peserta didik (Minsih \& Galih, 2018). Guru harus memiliki kompetensi sesuai dengan bidang keilmuannya, sehingga dengan kompetensi keilmuannya tersebut maka guru diharapkan mampu memberikan pembelajaran yang efektif dan efisien bagi pengembangan potensi peserta didik (Febriana, 2019).

Proses pembelajaran biasanya dilakukan di dalam atau luar kelas yang masih dalam satu lingkungan sekolah. Pembelajaran tatap muka tersebut memudahkan guru untuk mengatur proses belajar mengajar, misalnya guru memberikan studi kasus yang harus dipecahkan oleh peserta didik, maka secara tidak langsung hal tersebut dapat mendorong peserta didik untuk mengembangkan keterampilan berpikir kritis, kreatif dan inovatif, pemecahan masalah, serta kolaborasi (berkelompok).

Proses pembelajaran tatap muka yang biasanya dilakukan untuk saat ini diganti dengan pembelajaran daring atau online. Hal ini dikarenakan telah terjadi wabah virus covid-19 yang melanda Indonesia sejak Maret 2020 lalu (Supriatin, 2021). Wabah virus tersebut membuat pemerintah Indonesia memperlakukan aktivitas secara online, sehingga pekerjaan dilakukan dari rumah (Work From Home/WFH) (Haryanti, 2021). Fenomena tersebut membuat sekolah harus beradaptasi memberlakukan pembelajaran daring agar peserta didik tetap dapat belajar dengan baik.
Menurut Ningsih (2020) bahwa pembelajaran daring kepanjangan dari "dalam jaringan," dimana antara pengajar dan peserta didik melakukan proses belajar mengajar secara terpisah yang dihubungkan dengan jaringan internet. Menurut Muthuprasad, Aiswarya, Aditya, dan Jha (2021) pembelajaran daring memerlukan perangkat keras seperti laptop, handphone, tablet, komputer, dan smartphone. Selanjutnya Xhelili, Ibrahimi, Rruci, dan Sheme (2021) menjelaskan bahwa perangkat keras tersebut harus terhubung dengan jaringan internet.

Selain itu, menurut Mukhtar, Javed, Arooj, dan Sethi (2020) pembelajaran daring ini juga membutuhkan perangkat lunak (software) berbasis web untuk melakukan penyampaian materi. Perangkat lunak yang digunakan tersebut dapat berupa Google Meet, Microsoft Teams, Edmodo, Moodle, Zoom, Skype, WebEx, Adobe Connect dan lain sebagainya (Mukhtar, Javed, Arooj, \& Sethi, 2020; Muthuprasad, Aiswarya, Aditya, \& Jha, 2021). Pembelajaran daring juga dapat dilakukan dengan menggunakan aplikasi dan platform yang sering digunakan seperti whatsApp, telegram, youtube, google classroom, google form, google drive, massager facebook dan lain sebagainya (Anugrahana, 2020; Rosali, 2020).

Selain itu, guru memiliki tanggungjawab untuk menyiapkan perangkat yang lain sebagai pendukung proses pembelajaran. Seperti yang diungkapkan oleh Bunyamin, Rudiansyah, Hidayat, dan Suryani (2020) bahwa salah satu kompetensi guru yaitu pedagogi, dimana guru melakukan perencanaan, pelaksanaan, dan evaluasi pembelajaran. Perencanaan pembelajaran yang dilakukan oleh guru salah satunya menyiapkan perangkat pembelajaran. Rosilawati (2014); Isbianti dan Andriani (2021) menjelaskan lebih lanjut bahwa perangkat pembelajaran guru diantaranya silabus, Rencana Pelaksanaan Pembelajaran (RPP), bahan ajar/materi, media, dan penilaian.

Pembelajaran daring tersebut menjadi tantangan bagi sekolah khususnya guru yang harus berinovasi dalam menyampaikan ilmunya kepada peserta didik dengan baik. Berdasarkan beberapa penelitian dan fenomena yang ada di lapangan bahwa pembelajaran daring ini masih mengalami banyak kendala. Pembelajaran daring di lapangan masih terkendala dengan fasilitas sarana dan prasarana yang kurang mendukung dan guru belum menguasai aplikasi pembelajaran daring (Harahap, Dimyati, \& Purwanta, 2021).

Selain itu permasalahan ekonomi juga menghambat pembelajaran daring, dimana peserta didik yang orang tuanya memiliki kondisi ekonomi menengah ke bawah tidak sanggup untuk membeli kuota internet (Ota, Djou, \& Numba, 2021). Hal lain juga terjadi yaitu masalah akses jaringan yang susah terutama di daerah pedesaan (Mukminah, Wijaya, \& Hirlan, 2021). Selain itu, ketika pelaksanaan pembelajaran antara peserta didik dan guru 
kurang terjalin interaksi, sehingga peserta didik kurang maksimal dalam memahami materi (Suyahman, Ramadanti, Oktaviani, \& Wardhani, 2020).

Guru dalam mengembangkan potensi peserta didik dengan perlu mengintegrasikan dengan bidang keahliannya. Salah satu bidang keahlian yang diajarkan yaitu mata pelajaran ekonomi di tingkat Sekolah Menengah Atas (SMA). Bidang ilmu ini membahas tentang perilaku manusia untuk memenuhi kebutuhannya dengan melangsungkan kegiatan produksi, distribusi, dan konsumsi (Suharyadi, Purwanta, Saparuddin, Putra, \& Wulandari, 2014). Jadi dengan adanya mata pelajaran ekonomi ini, maka peserta didik belajar bagaimana cara memenuhi kebutuhannya agar dapat melangsungkan kehidupan dengan baik.

Mata pelajaran tersebut menurut Prahara dan Jamil (2018) lebih mengembangkan teori untuk menjelaskan fakta yang ada di lingkungan sekitar, karena ilmu ekonomi sangat erat hubungannya dengan kehidupan nyata. Selain itu, ilmu ekonomi memerlukan analisa untuk memecahkan suatu masalah. Mata pelajaran ekonomi SMA dalam peraturan kementerian pendidikan dan kebudayaan nomor 36/2018 memiliki alokasi waktu untuk kelas X sebanyak 3 jam/minggu, sedangkan kelas XI dan XII sebanyak 4 jam/minggu (Kemendikbud, Peraturan Menteri Pendidikan dan Kebudayaan Republik Indonesia Nomor 36 Tahun 2018, 2018). Alokasi waktu tersebut menurut Kemendikbud (2018) dalam peraturan nomor 37/2018 tersebar pada 24 Kompetensi Dasar (KD), dimana kelas X dan XI sebanyak 9 KD dan kelas XII sebanyak 6 KD.

Namun saat kondisi pandemi dengan sistem pembelajaran daring seperti saat ini, pemerintah mengeluarkan aturan bahwa satuan pendidikan diberikan kebebasan untuk melakukan proses pembelajaran. Salah satu kebebasan tersebut adalah terkait penuntasan materi pembelajaran, dimana melalui keputusan Menteri Pendidikan dan Kebudayaan Republik Indonesia Nomor 719/P/2020 bahwa satuan pendidikan tidak diwajibkan menyelesaikan materi dalam struktur kurikulum yang sudah ditetapkan untuk kenaikan kelas dan kelulusan (Kemendikbud, 2020 ).

Berdasarkan kondisi pembelajaran di masa pandemi covid-19 dan karakteristik mata pelajaran ekonomi, maka menjadi tantangan tersendiri bagi guru ekonomi bagaimana menerapkan pembelajaran secara daring, sehingga kompetensi peserta didik tetap dapat dikembangkan dengan efektif dan efisien. Berdasaran hal tersebut, maka penelitian ini akan menjelaskan lebih detail bagaimana guru ekonomi melakukan pembelajaran secara daring pada masa pandemi covid-19.

\section{METODE}

Penelitian ini termasuk jenis kualitatif, dimana melakukan kajian yang mendalam terhadap suatu gejala kemudian membuat kesimpulan dari gejala tersebut. Selanjutnya, penelitian ini tergolong dalam kualitatif analitik yaitu menggambarkan gejala secara rinci mulai dari apa, siapa, bagaimana, dimana, kapan, dan mengapa gejala tersebut diteliti (Harahap, 2020).

Penelitian ini dilakukan pada guru ekonomi SMA di Kota Solo, Kabupaten Boyolali, dan Kota Sukoharjo Jawa Tengah. Teknik yang digunakan purposive dan snowball sampling. Teknik purposive digunakan untuk memilih guru mata pelajaran yaitu ekonomi SMA, sedangkan teknik snowball digunakan memilih guru ekonomi SMA yang lain dari hasil rekomendasi yang pertama.

Penelitian ini mengumpulkan data dengan cara wawancara tidak terstruktur melalui sambungan video call dan telepon whatsApp. Hal ini dilakukan karena masih dalam kondisi pandemi covid-19. Data yang dikumpulkan berupa informasi mengenai sekolah tempat mengajar (namun dalam penulisan artikel ini, nama guru dan sekolah tidak dicantumkan), kualifikasi pendidikan guru ekonomi, jumlah jam mengajar, perencanaan pembelajaran ekonomi (penyiapan perangkat pembelajaran), proses pembelajaran (media dan model pembelajaran ekonomi), proses evaluasi pembelajaran (cara melakukan penilaian). Data yang sudah terkumpul kemudian dianalisis dengan model Miles dan Huberman. Menurut Miles dan Huberman dalam Sugiyono (2013) dijelaskan bahwa analisis data meliputi reduksi data, penyajian data, penarikan kesimpulan.

\section{HASIL DAN PEMBAHASAN}

\section{Hasil Penelitian \\ Guru Ekonomi A}

Wawancara dengan guru ekonomi A ini dilakukan pada Jum'at, 23 Juli 2021. Guru ekonomi A ini mengajar di salah satu sekolah swasta di Kota Solo, Jawa Tengah. Guru ekonomi A memiliki kualifikasi pendidikan S-2 Pendidikan Ekonomi dan mengajar dari kelas 10 - 12. Guru tersebut belum mengikuti Program Profesi Guru (PPG), sehingga belum memiliki sertifikat pendidik.

Pada awal tahun ajaran baru, guru ekonomi A menyiapkan perangkat pembelajaran untuk digunakan selama satu tahun ke depan. Perangkat tersebut meliputi silabus, RPP, media, bahan ajar, soal ulangan, dan penilaian. Perangkat pembelajaran tersebut dibuat untuk memenuhi syarat administrasi guru yang akan dilaporkan pihak sekolah kepada dinas pendidikan Provinsi Jawa Tengah. Hasil perangkat yang telah dibuat tersebut, sebagian besar tidak dilaksanakan pada proses pembelajaran. Hal ini dikarenakan jika pelaksanaannya 
sesuai dengan perangkat, maka materi tidak akan tersampaikan secara keseluruhan.

Pelaksanaan pembelajaran selama pandemi covid-19 dilakukan guru secara online dan Pembelajaran Tatap Muka Terbatas (PTMT). Pembelajaran online dilakukan guru ekonomi dengan memanfaatkan fasilitas yang ada di google, seperti google meet untuk proses tatap muka daring dengan peserta didik, google book sebagai bahan bacaan, dan google classroom untuk mendokumentasikan materi ekonomi, sehingga materi ekonomi tersampaikan secara keseluruhan.

Kegiatan PTMT dilakukan pihak sekolah dengan memberikan kesempatan kepada peserta didik sebanyak $50 \%$ secara bergiliran setiap minggu. Selanjutnya 50\% peserta didik yang lain tetap belajar secara online dengan materi yang sama dengan peserta didik yang PTMT. Hal ini membuat guru ekonomi harus mengajar dua kali yaitu di kelas PTMT dan online, sehingga sering dijumpai jadwal terbentur dengan guru atau kelas lain.

Selain itu untuk proses penilaian seperti ulangan harian, guru ekonomi menggunakan aplikasi seperti kahoot, quizizz, quipper school, mentimeter, dan google classroom. Penilaian tersebut dilakukan guru dengan berbagai aplikasi agar peserta didik termotivasi dalam mengerjakan soal. Khusus penilaian UTS dan PAS dikoordinasi oleh pihak sekolah, dimana pelaksanaannya diawasi melalui google meet, sehingga peserta didik dipastikan mengerjakan tepat waktu dan atas usahanya sendiri. Berdasarkan soal yang dibuat, guru ekonomi A membuat soal masih dalam kategori mudah yaitu antara ranah C1-C3.

Pembelajaran online yang dilakukan oleh sekolah ini dari sisi kuota dan fasilitas tidak ada masalah, karena peserta didik pada sekolah ini keadaannya menengah ke atas. Selain itu, dari pihak sekolah juga memberikan fasilitas kuota setiap bulan dari pemotongan uang SPP. Guru ekonomi juga tidak mengalami kendala dalam hal kuota dan fasilitas, karena proses mengajar menggunakan wifi sekolah. Namun, ada kendala yang dirasakan guru ekonomi ketika mengajar yaitu terbenturnya jadwal antar kelas dan guru lain, peserta didik mengalami masalah jaringan karena didaerahnya susah mendapatkan sinyal, dan masih banyak peserta didik yang malas mengerjakan tugas dan mengikuti proses pembelajaran online.

\section{Guru Ekonomi B}

Wawancara dengan guru ekonomi B ini dilakukan pada Jum'at, 23 Juli 2021. Guru ekonomi B ini mengajar di salah satu sekolah negeri di Kabupaten Sukoharjo, Jawa Tengah. Guru ekonomi B memiliki kualifikasi pendidikan S-2 Pendidikan Ekonomi dan mengajar dari kelas 10. Guru tersebut belum mengikuti Program Profesi Guru (PPG), sehingga belum memiliki sertifikat pendidik.
Pada awal tahun ajaran baru atau sebelum proses pembelajaran di mulai guru ekonomi $B$ ini juga mempersiapkan perangkat pembelajaran seperti RPP, silabus, prota - promes, materi, media, model, dan penilaian. Perangkat yang dibuat tersebut dibuat secara online, meskipun ada PTMT. Perangkat tersebut dibuat hanya untuk memenuhi administrasi saja, sedangkan untuk penerapan pada proses pembelajaran tidak sesuai dengan yang direncanakan. Hal ini dikarenakan jika pelaksanaannya sesuai dengan perangkat, maka materi tidak akan tersampaikan secara keseluruhan.

Pada proses pembelajaran dilakukan secara online ketika awal pandemi, selanjutnya setelah semester genap sekolah menetapkan kebihakan PTMT. Proses pembelajaran online dilakukan oleh guru ekonomi dengan cara menyampaikan materi melalui whatsApp group (WAG) dan google classroom. Guru ekonomi memberikan modul/link materi melalui WAG, sedangkan jika materi dalam bentuk video di upload pada google classroom.

Selanjutnya ketika semester genap, guru ekonomi melakukan PTMT dengan fasilitas dari sekolah. Jumlah peserta didik yang boleh mengikuti PTMT hanya 50\% dan sisanya tetap belajar secara online. Kelas yang mengikuti PTMT yaitu kelas yang sama sampai akhir semester genap. Proses pembelajaran pada PTMT ini berbeda dengan yang full online. Pada PTMT ini, sekolah menyediakan kamera di setiap kelas, peserta didik yang belajar online tetap mengikuti proses pembelajaran melalui fasilitas live streaming.

Selanjutnya untuk proses penilaian ulangan harian dan UTS dilakukan guru ekonomi melalui google classroom. Peserta didik dapat login ke akun google classroom masing-masing dan mengerjakan soalnya. Selain itu, khusus penilaian PAS dikoordinir oleh pihak sekolah yaitu menggunakan aplikasi e-learning khusus sekolah tersebut. Pelaksanaan PAS juga dilakukan serentak, jadi peserta didik yang terlambat tidak bisa melakukan susulan, kecuali dalam kondisi sakit. Soal ekonomi dibuat dengan ranah HOTS yaitu C3 - C6 dan kebanyakan dibuat pilihan ganda, sehingga mempermudah dalam mengkoreksinya. Ranah soal HOTS dibuat oleh guru ekonomi agar peserta didik tidak hanya menyalin jawaban, akan tetapi mereka juga perlu berpikir untuk menyelesaikan soal tersebut.

Kendala yang dialami oleh guru ekonomi B ini yaitu pada masalah keaktifan peserta didik ketika proses pembelajaran. Banyak dari peserta didik yang tidak melakukan absen, tidak mengumpulkan tugas, dan tidak mengikuti proses pembelajaran. Selain itu, pihak sekolah tidak memberikan bantuan kuota, sehingga sebagian peserta didik merasa keberatan jika harus melakukan live streaming. Namun, jika peserta didik tidak memiliki handphone/laptop/komputer di rumah, maka dapat 
memakai fasilitas sekolah berupa lab komputer/laptop dan mengikuti pembelajaran di sekolah.

\section{Guru Ekonomi C}

Informasi yang diperoleh dari guru ekonomi $\mathrm{C}$ yaitu melalui kegiatan wawancara yang dilakukan pada Senin, 26 Juli 2021. Guru ekonomi C ini mengajar di salah satu sekolah negeri di Kabupaten Boyolali, Jawa Tengah. Guru ekonomi tersebut belum memiliki sertifikat pendidikan, tetapi beliau sudah menyelesaikan studi S-2 Pendidikan Ekonomi. Guru ekonomi C ini melakukan pembelajaran selama pandemi covid-19 secara online dan belum menerapkan pembelajaran PTMT.

Pada awal tahun pelajaran, guru ekonomi ini membuat perangkat pembelajaran seperti RPP, silabus, media, model, dan penilaian. Perangkat tersebut hanya digunakan sebagai syarat administrasi guru, sedangkan untuk pelaksanaan/proses pembelajaran tidak sesuai dengan yang sudah direncanakan. Perangkat yang dibuat oleh guru ekonomi ini di setting dengan pelaksanaan pembelajaran blended learning, meskipun pembelajaran masih dilakukan secara online. Hal ini dilakukan karena perintah dari kepala sekolah untuk membuat perangkat dengan sistem onlineoffline (blended learning).

Proses pembelajaran yang dilakukan oleh guru ekonomi $\mathrm{C}$ ini dengan memanfaatkan media online seperti google classroom dan WAG. Guru ekonomi melakukan upload materi melalui google classroom, kemudian untuk penjelasan dilakukan melalui WAG. Materi yang di upload pada google classroom tersebut berupa file pdf, ppt, dan video dari link youtube. Proses pembelajaran online ini hanya dibatasi maksimal 60 menit untuk 2 jam pelajaran, sehingga materi ekonomi tidak disampaikan secara keseluruhan oleh guru ekonomi. Hal ini dikarenakan waktu yang dibutuhkan tidak cukup, guru ekonomi hanya memilih materi yang sekiranya penting/sering keluar untuk ujian.

Pemerintah dan sekolah tempat mengajar guru ekonomi C juga memberikan bantuan berupa kuota internet pada awal pandemi covid-19, sehingga proses pembelajaran tetap dapat berjalan dengan baik. Akan tetapi setelah itu, bantuan tidak diberikan lagi, sehingga banyak peserta didik yang mengeluhkan tentang kuota internet. Selain itu dari pihak sekolah juga memberikan bantuan handphone bagi peserta didik yang benar-benar tidak memiliki fasilitas online seperti handphone/laptop/komputer. Hal ini dikarenakan mayoritas peserta didik berada pada kondisi ekonomi keluarga menengah ke bawah.

Proses evaluasi untuk menilai ulangan harian, UTS, dan PAS dilakukan melalui google form. Khusus untuk ulangan harian, guru ekonomi $\mathrm{C}$ ini juga menggunakan quizizz. Bentuk soal yang digunakan berupa pilihan ganda, sehingga peserta didik tinggal menjawab soal yang telah tersedia. Bentuk soal tersebut memberikan kemudahan bagi guru untuk mengkoreksinya. Kelemahan dari evaluasi yang dilakukan guru ekonomi yaitu tidak bisa mengawasi peserta didik ketika menjawab soal, sehingga hasil jawaban peserta didik tidak bisa diketahui apakah hanya menyalin, mengerjakan sendiri, atau dikerjakan orang lain.

Kendala yang dialami oleh guru ekonomi C ini selama pembelajaran online yaitu masalah keaktifan peserta didik selama proses pembelajaran. Banyak dari peserta didik tidak bergabung di kelas ekonomi ketika sudah waktu jam pelajaran, sehingga guru ekonomi harus mengkonfirmasi satu per satu peserta didik yang belum bergabung.

\section{Pembahasan}

Hasil penelitian dengan melakukan wawancara guru ekonomi SMA di Kota Solo, Kabupaten Boyolali, dan Kota Sukoharjo bahwa pembelajaran pada masa pandemi Covid19 yang dilakukan meliputi perencanaan, pelaksanaan, dan penilaian. Kegiatan tersebut memang sudah menjadi tugas pokok bagi seorang guru dalam kompetensi pedagogi (Bunyamin, Rudiansyah, Hidayat, \& Suryani, 2020).

\section{Perencanaan Pembelajaran}

Tahap awal sebelum guru ekonomi melakukan proses pembelajaran, maka perlu melakukan persiapan/perencanaan terlebih dahulu. Perencanaan ini meliputi persiapan perangkat pembelajaran yang akan dilakukan satu tahun mendatang. Perangkat pembelajaran tersebut meliputi silabus, RPP, media, materi, dan evaluasi (Rosilawati, 2014; Isbianti \& Andriani, 2021).

Adanya pandemi Covid-19 saat ini, maka perangkat yang dibuat juga harus disesuaikan dengan kondisi pembelajaran daring. Hal tersebut juga dilakukan oleh guru ekonomi, dimana dalam pembuatan perangkat di setting secara daring. Guru ekonomi hanya fokus pada pembuatan RPP saja, karena perangkat tersebut harus dilaporkan kepada dinas pendidikan. Pembuatan RPP tersebut hanya mengedit sesuai dengan tahun sebelumnya. Hal ini sesuai dengan penelitian yang dilakukan oleh Ayuni, Marini, Fauziddin, dan Pahrul (2021) bahwa pembuatan RPP harus disesuaikan dengan kondisi pembelajaran daring.

Rancangan Perangkat Pembelajaran (RPP) yang dibuat oleh guru ekonomi tersebut juga dilengkapi metode, media, alat dan bahan, serta penilaian. Namun, media, alat dan bahan, serta penilaian tersebut hanya sebatas tulisan di dalam RPP saja. Komponen tersebut tidak dipersiapkan ketika menyusun perangkat pembelajarannya. Hal itu dikarenakan waktu yang dibutuhkan untuk membuat komponen tersebut sangat terbatas, sedangkan RPP harus dikumpulkan ke dinas pendidikan sebagai syarat administrasi. Hal ini menurut Arifin dan Hala (2018) bahwa biasanya guru membuat RPP hanya untuk memenuhi syarat administrasi. 
Selanjutnya rencana pembelajaran yang tertulis pada lembar RPP tersebut tidak seluruhnya diterapkan sesuai perencanaan karena kendala waktu. Apabila guru ekonomi melaksanakan pembelajaran sesuai RPP, maka materi ekonomi tidak dapat diselesaikan secara keseluruhan, apalagi pada kondisi pembelajaran daring seperti ini. Hal ini sesuai penelitian yang dilakukan Sudirman (2013) bahwa proses pembelajaran tidak sesuai dengan rencana pembelajaran. Seharusnya apabila guru membuat rencana pembelajaran sesuai dengan kondisi yang ada, maka rencana tersebut dapat terlaksana dengan baik.

\section{Pelaksanaan Pembelajaran}

Tahap pelaksanaan kegiatan pembelajaran ekonomi ini berbeda dengan pembelajaran sebelum pandemi covid-19. Pada saat sekarang ini guru ekonomi harus mengajar dengan menggunakan media online. Guru ekonomi melakukan pembelajaran dengan menggunakan aplikasi seperti WhatsApp Group, Google Classroom, Google Meet dan youtube. Hal ini sesuai dengan Anugrahana (2020) dan Rosali (2020) bahwa pembelajaran daring dapat dilakukan dengan menggunakan aplikasi dan platform seperti whatsApp, telegram, youtube, google classroom, google form, google drive, massager facebook dan lain sebagainya.

Penggunaan aplikasi untuk pembelajaran ekonomi tersebut dirasakan oleh guru ekonomi lebih mudah dalam pengoperasiannya. Selain itu peserta didik juga banyak yang menggunakan aplikasi tersebut, sehingga peserta didik dapat mengikuti pembelajaran dengan baik. Secara tidak langsung hal ini sesuai dengan yang diungkapkan oleh Susilana dan Riyana (2009) bahwa perancangan media pembelajaran harus mudah diakses dan didukung dengan teknologi yang sudah ada. Guru ekonomi dalam hal ini sudah menyesuaikan dengan kondisi masing-masing peserta didik.

Selanjutnya dalam penyampaian materi selama pembelajaran daring, guru ekonomi tidak berpedoman dengan RPP yang sudah dibuat. Menurut-nya apabila mengikuti RPP, materi ekonomi tidak dapat tersampaikan dengan efektif. Jadi guru ekonomi hanya mengambil materi ekonomi yang dirasa penting dan perlu untuk diketahui oleh peserta didik. Cara guru ekonomi tersebut tidak menyalahi aturan, karena selama pembelajaran daring ini Kemendikbud telah mengeluarkan keputusan Nomor 719/P/2020 bahwa satuan pendidikan tidak diwajibkan menyelesaikan materi dalam struktur kurikulum yang sudah ditetapkan untuk kenaikan kelas dan kelulusan (Kemendikbud, 2020 ).

\section{Penilaian Pembelajaran}

Tahap terakhir dari tugas guru yaitu melakukan penilaian belajar. Guru ekonomi melaksanakan penilaian selama pembelajaran daring menggunakan cara online.
Guru ekonomi memanfaatkan berbagai fasilitas online seperti google form, quizzezz, quipper school, mentimeter, kahoot, serta software e-learning milik sekolah. Hal yang dilakukan oleh guru ekonomi tersebut sesuai pendapat dari Andari (2020); Mulatsih (2020); Mahariyanti dan Hadi (2020); Andrini dan Pratama (2021) bahwa penilaian hasil belajar dapat dilakukan menggunakan aplikasi seperti kahoot, google form, mentimeter, kerjasama dengan quipper school, quizzizz.

Selanjutnya soal yang dibuat guru berupa pilihan ganda, sehingga hasil akhirnya bisa dilihat secara langsung. Soal yang dibuat tersebut memuat kategori memahami, mengaplikasikan, mengevaluasi, dan menganalisis. Jadi guru ekonomi disini membuat soal disesuaikan dengan tingkatan taksonomi Bloom dari C2, C3, C4, dan C5. Hal ini sesui dengan yang diharapkan dalam kurikulum 2013 yaitu mendorong peserta didik untuk mengembangkan berpikir tingkat tinggi (Oktanisa \& Fitrayati, 2018). Pembuatan soal ekonomi tersebut dilakukan guru untuk mengukur kemampuan tingkat tinggi (Higher Order Thinking Skills/HOTS), meskipun belum sepenuhnya menggunakan indikator HOTS. Menurut Widiawati, Joyoatmojo, dan Sudiyanto (2018) bahwa HOTS dapat diukur dengan menggunakan indikator C4 (menganalisis), C5 (Mengevaluasi), dan C6 (Mencipta).

\section{SIMPULAN}

Penelitian ini dapat disimpulkan bahwa dalam pelaksanaan pembelajaran daring guru ekonomi tetap melakukan tugas membuat rencana pembelajaran, dalam hal ini guru ekonomi membuat perangkat administrasi sebelum proses pembelajaran dimulai. Waktu pembuatan sebelum memasuki tahun ajaran baru. Perangkat pembelajaran tersebut dibuat dengan menyesuaikan pembelajaran daring dan hanya mengedit dari perangkat pembelajaran tahun sebelumnya. Guru ekonomi dalam melakukan pelaksanaan pembelajaran menggunakan media online seperti WhatsApp Group, Google Classroom, Google Meet dan youtube. Selanjutnya untuk penilaian pembelajaran, guru ekonomi menggunakan aplikasi google form, quizzezz, quipper school, mentimeter, kahoot, serta software $e$-learning milik sekolah.

Penelitian ini dapat menjadi masukan bagi pendidik khususnya guru ekonomi dalam melaksanakan pembelajaran daring. Selanjutnya, penelitian ini masih memiliki keterbatasan dalam pengambilan data, dimana penelitian hanya melakukan pengambilan data di sekolah SMA wilayah Surakarta. Diharapkan untuk peneliti selanjutnya dapat menambah pengambilan data pada wilayah lainnya. 


\section{DAFTAR PUSTAKA}

Andari, R. (2020). Pemanfaatan Media Pmbelajaran Berbasis Game Edukasi Kahoot! Pada Pembelajaran Fisika. ORBITA: Jurnal Hasil Kajian, Inovasi, dan Aplikasi Pendidikan Fisika, 6(1), 135 137. doi:https://doi.org/10.31764/orbita.v6i1.2069

Andrini, V. S., \& Pratama, H. (2021). Implementasi Quiz Interaktif dengan Software Mentimeter dalam Meningkatkan Hasil Belajar . Jurnal Mimbar Ilmu, 26(2), $287 \quad-\quad 294$. doi:http://dx.doi.org/10.23887/mi.v26i2.36923

Anugrahana, A. (2020). Hambatan, Solusi dan Harapan: Pembelajaran daring Selama Masa Pandemi Covid-19 oleh Guru Sekolah Dasar. Scholaria: Jurnal Pendidikan dan Kebudayaan, 10(3), 282 289.

doi:https://doi.org/10.24246/j.js.2020.v10.i3.p28 2-289

Arifin, A. N., \& Hala, Y. (2018). Pelatihan Penyusunan Perangkat Pembelajaran Biologi Berdasarkan Kurikulum 2013 pada Guru Biologi Kota Makassar. Seminar Nasional Pengabdian Kepada Masyarakat. 5, hal. 369 - 371. Makassar: LPPM Universitas Negeri Makassar. Dipetik Agustus 8, 2021

Ayuni, D., Marini, T., Fauziddin, M., \& Pahrul, Y. (2021). Kesiapan Guru TK Menghadapi Pembelajaran Daring Masa Pandemi Covid-19. Jurnal Obsesi: Jurnal Pendidikan Anak Usia Dini, 5(1), 414 421. doi:10.31004/obsesi.v5i1.579

Bunyamin, Rudiansyah, R., Hidayat, E., \& Suryani, E. (2020). Kepala Sekolah dalam Supervisi Akademik. Syntax Idea, 2(12), 1028 - 1035. Diambil kembali dari https://www.jurnal.syntaxidea.co.id/index.php/syntaxidea/article/view/791

Depdiknas. (2003). Undang-Undang Republik Indonesia Nomor 20 Tahun 2003 Tentang Sistem Pendidikan Nasional. Jakarta: Sekretaris Negara Republik Indonesia.

Dhawan, S. (2020). Online Learning: A Panacea in the Time of Covid-19 Crisis. Journal of Educational Technology Systems, 49(1), 5 - 22. doi:https://doi.org/10.1177/0047239520934018

Febriana, R. (2019). Kompetensi Guru. Jakarta: Bumi Aksara.

Harahap. (2020). Penelitian Kualitatif. Medan: Wal Ashri Publishing.

Harahap, S. A., Dimyati, \& Purwanta, E. (2021). Problematika Pembelajaran Daring dan Luring Anak Usia Dini bagi Guru dan Orang Tua di Masa Pandemi Covid-19. Jurnal Obsesi: Jurnal Pendidikan Anak Usia Dini, 5(2), 1825-1836. doi:https://doi.org/10.31004/obsesi.v5i2.1013
Haryanti, R. (2021, Maret 2). Kompas News. (I. Maullana, Editor) Diambil kembali dari Kompas.com: https://megapolitan.kompas.com/read/2021/03/0 2/15304221/setahun-covid-19-jakarta-jadiprovinsi-pertama-yang-tutup-sekolah-danwfh?page $=$ all

Isbianti, P., \& Andriani, D. E. (2021). Pelaksanaan Supervisi Akademik oleh Kepala Sekolah Menengah Pertama Negeri di Klaten Jawa Tengah. Jurnal Manajemen Pendidikan , 3(1), 75 - 85. Diambil kembali dari https://journal.uny.ac.id/index.php/jmp/article/vi ew/39020

Karim, M. (2020). Keterampilan Abad 21 dan Desain Pembelajarannya. Proceeding International Conference on Islamic Education. 5, hal. 161169. Malang: Faculty of Tarbiyah and Teaching Training, Universitas Islam Negeri Maulana Malik Ibrahim Malang. Diambil kembali dari $\mathrm{http} / / /$ conferences.uin-

malang.ac.id/index.php/icied/article/view/1240

Kemendikbud. (2018). Peraturan Menteri Pendidikan dan Kebudayaan Republik Indonesia Nomor 36 Tahun 2018. Jakarta: Kepala Biro Hukum dan Organisasi Kementerian Pendidikan dan Kebudayaan.

Kemendikbud. (2018). Peraturan Menteri Pendidikan dan Kebudayaan Republik Indonesia Nomor 37 Tahun 2018. Jakarta: Kepala Biro Hukum dan Organisasi Kementerian Pendidikan dan Kebudayaan

Kemendikbud. (2020 ). Keputusan Menteri Pendidikan dan Kebudayaan Republik Indonesia Nomor 719/P/2020 tentang Pedoman Pelaksanaan Kurikulum Pada Satuan Pendidikan dalam Kondisi Khusus. Jakarta: Kepala Biro Hukum Kementerian Pendidikan dan Kebudayaan

Mahariyanti, E., \& Hadi, S. (2020). Efektivitas Penggunaan Blended Learning dengan Platform Quipper School terhadap Hasil Belajar Peserta Didik Mata Pelajaran Biologi Kelas XI MIPA di SMAN 2 Selong. Jurnal Ilmiah Wahana Pendidikan, 6(4), $911 \quad$ - 920. doi:https://doi.org/10.5281/zenodo.4314057

Minsih, \& Galih, A. (2018). Peran Guru dalam Pengelolaan Kelas . Profesi Pendidikan Dasar, $\begin{array}{llll}5(1), & 20 & - & 27\end{array}$ doi:https://doi.org/10.23917/ppd.v1i1.6144

Mukhtar, K., Javed, K., Arooj, M., \& Sethi, A. (2020). Advantages, Limitations and Recommendations for Online Learning during COVID-19 Pandemic Era. Pakistan Journal of Medical Sciences, 36(COVID19-S4), $27 \quad-\quad 31$. doi:https://doi.org/10.12669/pjms.36.COVID19S4.2785 
Mukminah, Wijaya, H., \& Hirlan. (2021). Problematika Pembelajaran Saat Pandemi Covid-19 di Madrasah Ibtidaiyah Nurul Ulum Mertak Tombok. Jurnal Ilmu Sosial dan Pendidikan, 5(1), 320-326. doi:http://dx.doi.org/10.36312/jisip.v5i1.1700

Mulatsih, B. (2020). Penerapan Aplikasi Google Classroom, Google Form, dan Quizzizz dalam Pembelajaran Kimia di Masa Pandemi Covid-19. Ideguru: Jurnal Karya Ilmiah Guru, 5(1), 16 - 26.

Muthuprasad, T., Aiswarya, S., Aditya, K., \& Jha, G. K. (2021). Students' Perception and Preference for Online Education in India during COVID -19 Pandemic. Social Sciences \& Humanities Open, 3(1), $\quad 1 \quad-\quad 11$. doi:https://doi.org/10.1016/j.ssaho.2020.100101

Ningsih, S. (2020). Persepsi Mahasiswa Terhadap Pembelajaran Daring Pada Masa Pandemi Covid19. Jurnal Inovasi Teknologi Pembelajaran, 7(2), $124 \quad$ - $123 . \quad$ doi: http://dx.doi.org/10.17977/um031v7i22020p124

Oktanisa, L., \& Fitrayati, D. (2018). Pengembangan Asesmen Soal Berbasis Higher Order Thinking Skills Pada Mata Pelajaran Ekonomi. Jurnal Pendidikan Ekonomi, 6(3), 355 - 361. doi:https://doi.org/10.26740/jupe.v6n3.p\%25p

Ota, M. K., Djou, A. M., \& Numba, F. F. (2021). Problematika Pembelajaran Daring Siswa Kelas VII SMPN 1 Ende Selatan, Kabupaten Ende. Mitra Mahajana: Jurnal Pengabdian Masyarakat, $\quad 2(1), \quad 74-81$. doi:https://doi.org/10.37478/mahajana.v2i1.769

Pamungkas, W. W. (2021, Maret 19). Kabar Jabar. Diambil kembali dari bisnis.com: https://bandung.bisnis.com/read/20210319/549/ 1369755/disdik-jabar-apresiasi-pembagiantablet-untuk-siswa-belajar-daring

Prahara, R. S., \& Jamil, A. S. (2018). Konsep Pembelajaran Ekonomi Berbasis Ekonomi Kreatif. Indonesian Interdisciplinary Journal of Sharia Economics (IIJSE), 1(1), 7-18. doi:https://doi.org/10.31538/iijse.v1i1.68

Redhana, I. W. (2019). Mengembangkan Keterampilan Abad ke-21 dalam Pembelajaran Kimia. Jurnal Inovasi Pendidikan Kimia, 2239-2253. Diambil kembali dari https://journal.unnes.ac.id/nju/index.php/JIPK/ar ticle/view/17824

Rosali, E. S. (2020). Aktifitas Pembelajaran daring Pada Masa Pandemi Covid-19 di Jurusan Pendidikan Geografi Universitas Siliwangi Tasikmalaya. Geography Science Education Explored Journal, 1(1), 21 - 30. Diambil kembali dari http://jurnal.unsil.ac.id/index.php/geosee/article/ view/1921
Rosilawati, T. (2014). Supervisi Akademik dalam Upaya Peningkatan Motivasi Guru Menyusun Perangkat Persiapan Pembelajaran. Jurnal Penelitian Tindakan Sekolah dan Kepengawasan, 2(2), 57 62. Diambil kembali dari http://irpp.com/index.php/jptsk/article/view/180

Saftiani, T. (2021, Maret 2). Pendidikan. Diambil kembali dari Pikiran Rakyat Cirebon.com: https://cirebon.pikiranrakyat.com/pendidikan/pr-041518708/fasilitasipembelajaran-daring-kemendikbud-beribantuan-kuota-data-internet-tahun-2021

Sudirman, D. (2013). Kesesuaian Antara Persiapan Mengajar dengan Pelaksanaan Pembelajaran oleh Guru IPA SMP Negeri Se-Kecamatan Lengayang Kabupaten Pesisir Selatan. Simbiosa, 2(2), 61 65.

Sugiyono. (2013). Metode Penelitian Kuantitatif, Kualitatif, dan $R \& D$. Bandung: Alfabeta.

Suharyadi, Purwanta, W., Saparuddin, Putra, E., \& Wulandari, A. (2014). Kurikulum 2013: Pedoman Guru Mata Pelajaran Ekonomi untuk Sekolah Menengah Atas (SMA)/Madrasah Aliyah (MA). Jakarta: Kementerian Pendidikan dan Kebudayaan.

Supriatin. (2021, Maret 3). Merdeka Peristiwa. Diambil kembali dari Merdeka.com: https://www.merdeka.com/peristiwa/satgas-ribuktikan-pengendalian-covid-19-paraleldengan-menjaga-sosial-ekonomi.html

Susilana, R., \& Riyana, C. (2009). Media Pembelajaran: Hakikat, Pengembangan, Pemanfaatan, dan Penilaian. Bandung: CV Wacana Prima.

Suyahman, Ramadanti, F., Oktaviani, D., \& Wardhani, D. P. (2020). Problematika dalam Pembelajaran PPKN pada Era Covid-19 di SMA Negeri 3 Sukoharjo. PKn Progresif: Jurnal Pemikiran dan Penelitian Kewarganegaraan, 15(2), 68-77. doi:https://doi.org/10.20961/pknp.v15i2.47951

Valtonen, T., Hoang, N., Sointu, E., Naykki, P., Virtanen, A., Poysa-Tarhonen, J., . . Kukkonen, J. (2021). How Pre-service Teachers Perceive their 21stcentury Skills and Dispositions: A Longitudinal Perspective. Computer and Human Behavior, 116, 1-9. doi:https://doi.org/10.1016/j.chb.2020.106643

Widiawati, L., Joyoatmojo, S., \& Sudiyanto. (2018). Higher Order Thinking Skills as Effect of Problem Based Learning in the 21st Century Learning. International Journal of Multicultural and Multireligious Understanding, 5(3), 96 - 105. Diambil kembali dari https://ijmmu.com/index.php/ijmmu/article/view /223/139 
Widodo, S., \& Wardani, R. K. (2020). Mengajarkan Keterampilan Abad 21 4C (Communication, Collaboration, Critical Thinking, and Problem Solving, Creativity and Innovation) di Sekolah Dasar. Modeling: Jurnal Program Studi PGMI, $7(2)$, 185-197. doi:https://doi.org/10.36835/modeling.v7i2.665

Xhelili, P., Ibrahimi, E., Rruci, E., \& Sheme, K. (2021). Adaptation and Perception of Online Learning during Covid-19 Pandemic by Albanian University Students. International Journal on Studies in Education, 3(2), 103 - 111. doi:https://doi.org/10.46328/ijonse.49 